\title{
TUGAS REVIEW PEREKONOMIAN INDONESIA
}

\author{
Nama : Inggrid Elier \\ NRP : 130218307 \\ KP : A
}

\section{The Impact of Minister of Marine Affairs and Fisheries Regulation Number 12 of 2020 on the Sustainability of Lobster in Indonesia}

\section{Introduction}

The case of lobster extinction has become the most common thing in Indonesia. As is well known, lobster is one of the most preferred foods by many Indonesians. Female lobster is one of the most desirable animals for humans. This made the lobsters slowly become extinct.

Indonesia is a country that has a very large archipelago which is surrounded by vast oceans. Living things certainly live in the sea, the living things that are meant in this case are lobsters, crabs, fish and many more. As already mentioned, lobsters have a very high demand so that they become the target of fishing by fishermen.

With the high demand for lobsters, it provides opportunities for fishermen to be able to supply lobsters to the market at high prices. In a business, high demand will also make prices high. Unfortunately, however, the fishermen experienced a problem and difficulty catching these lobsters. This is because the equipment owned by some fishermen is inadequate. When sailing, fishermen need a place to store the nets or else the nets will be lost at sea and make the fishing a failure.

So through this problem, the government has established a new policy which provides facilities and benefits for fishermen to be able to sail and catch lobsters as their source of livelihood. It is known that the government has set a new policy in law number 12 in 2020 . The government has conducted an investigation regarding the case of fishermen who suffered losses and found it difficult to find a livelihood. Through this investigation, it was found that 13,000 fishermen had problems related to legalization and the equipment they used.

The problems arising from the equipment used involve conflicts between the Indonesian Navy and the fishermen. Fishing equipment is one of the things that must be considered because it is a required item for fishermen. Lobster gives a very high demand, because of the high demand, a new lobster policy was given, which must be practiced by all fisherman and others. As is well established, the aim of this policy is to assist fishermen, which means that the survival of all lobsters would be overlooked and endangered.

The survival of a lobster is a very important matter because it is an animal that is rare and it's difficult to find. The scarcity of lobsters is due to the fact that lobster seeds are often caught 
and sold. So it would be better if the male lobsters were caught. Cultivation of lobsters needs to be done in order to prevent the extinction of all lobsters in this country.

This study aims to discuss the policies implemented by the government and also their relation to the sustainability of lobster life. As it is said before, although the matter of fishermen problem is important, but the life of lobsters is also an important matter to deal with. Through this research, it is hoped that all readers can discover and see the important of the cultivation of a lobster in the sea.

\section{Research Discussion}

The government established a new policy to provide benefits for fishermen and also the survival of lobsters in the sea. However, it is very unfortunate because some parties thought that the government prefers to help fishermen and profit to exporters compared to cultivating these lobsters. The policies provided by the government contain the benefits and benefits that fishermen and exporters can get in generating income and for lobsters that are almost extinct.

Through this policy, the parties related to lobsters, namely companies and exporters, need to cultivate these lobsters to maintain their survival. In this study, it was found that as many as 30 companies have been involved in the lobster cultivation process which must be carried out in accordance with the policy.

PT. Tania Asia Marina is one company that has successfully followed the new policy and has obtained a total of 139,475,000 lobsters. The number of lobsters is of course not only from one company but from 30 companies involved. The results of the cultivation are the results that are given for a full year.

\section{Conclusion}

The extinction of lobsters is no longer in doubt, the high demand makes lobsters a target for fishermen to sell to the market. The problem in this research is the problem of fishermen who cannot make a living because of legalization and inadequate equipment. So through the discussion of this research, it is found that there is justice in the policies provided by the government. Several conclusions were discovered as a result of the research, including the market for lobsters and how this policy's adoption will help all parties.

The party that is declared as differentiated is the sea party, namely lobster and also the exporter. So in fact of this, the parties who object and have different views think that this new policy is only given to provide more opportunities for exporters to be able to sell and make money. Not for the survival of the lobsters. However, as already stated, legalization related to export has a good impact on lobsters as well.

The new policy that was given ensures that all exporters take part in helping to cultivate lobsters' sustainability so that they are no longer extinct and will survive. In addition to thinking 
about profits and sales, they, namely companies and exporters, will participate and be involved in this lobster cultivation. So through this research a policy was found in which the government has provided policies to benefit both parties, not just all exporters.

\section{Reference}

Tayibnapis, A. Z., Wuryaningsih, L. E., \& Gora, R. (2020). The Impact of Minister of Marine Affairs and Fisheries Regulation Number 12 of 2020 on the Sustainability of Lobster in IndonesiaThe Impact of Minister of Marine Affairs and Fisheries Regulation Number 12 of 2020 on the Sustainability of Lobster in Indone. International Journal of Multicultural and Multireligius Understanding. 